\title{
Impaired Innate Immunity Mechanisms in the Brain of Alzheimer's Disease
}

\author{
Martina Romagnoli ${ }^{1,+}+$ (D) Elisa Porcellini ${ }^{1, *,+}$, Ilaria Carbone ${ }^{1}$, Robert Veerhuis ${ }^{2,3(1)}$ and \\ Federico Licastro ${ }^{1}$ \\ 1 Department of Experimental, Diagnostic and Specialty Medicine, School of Medicine, University of Bologna, \\ Via S. Giacomo 14, 40126 Bologna, Italy; martina.romagnoli87@gmail.com (M.R.); \\ ilaria.carbone2@unibo.it (I.C.); federico.licastro@unibo.it (F.L.) \\ 2 Department of Clinical Chemistry, Vrije Universiteit Amsterdam, Amsterdam UMC, 1105 Amsterdam, \\ The Netherlands; r.veerhuis@amsterdamumc.nl \\ 3 Department of Psychiatry, Vrije Universiteit Amsterdam, Amsterdam UMC, 1105 Amsterdam, \\ The Netherlands \\ * Correspondence: elisa.porcellini3@unibo.it; Tel.: +39-051-2094706 \\ + These authors contributed equally to this work.
}

Received: 20 December 2019; Accepted: 5 February 2020; Published: 8 February 2020 updates

\begin{abstract}
Among environmental factors likely associated with Alzheimer's disease (AD), persistent virus infections, and age-related progressive decline of immune competence might play a pivotal role. However, $\mathrm{AD}$ antimicrobial brain immune responses are poorly investigated. The present study focused on genes involved in antimicrobial defenses, especially against virus infections, in the AD brain. In particular, mRNA levels of IRF7, MED23, IL28B, and IFN- $\alpha$ genes were analyzed in hippocampus and temporal cortex brain samples from $\mathrm{AD}$ and non-demented controls. All subjects were also genotyped for APOE $\varepsilon$, IRF7, MED23, and IL28B gene polymorphisms. Most AD patients showed decreased mRNA levels of all investigated genes in the hippocampus and temporal cortex. However, a small group of AD patients showed increased hippocampal mRNA expression of MED23, IL28B, and IFN- $\alpha$. mRNA levels of MED23, IL28B, IFN- $\alpha$ from the hippocampus and those of MED23 from the temporal cortex were further decreased in APOE $\varepsilon 4$ allele AD carriers. Moreover, rs6598008 polymorphism of IRF7 was significantly associated with decreased hippocampal expression of IRF7, MED23, IL28B, and IFN- $\alpha$. These findings suggest that AD brains show impaired innate antimicrobial gene expression profiles, and individual genetic makeup, such as positivity for the APOE $\varepsilon 4$ and IRF7 A alleles, might affect brain immune efficiency.
\end{abstract}

Keywords: Alzheimer's disease; viral infection; antiviral genes; gene expression; brain immunity

\section{Introduction}

Alzheimer's disease (AD) is a chronic neurodegenerative disease and the most frequent form of dementia in the elderly [1]. It is of interest that declining immunity during aging is often associated with persistent antigen stimulation and peripheral chronic inflammation [2]. Moreover, neuroinflammation has emerged as a relevant component of AD brain pathology [3].

Pathogens, such as viruses of the herpes family, through frequent cycles of reactivation and latency, constantly trigger the immune system, which is not able to completely eradicate these microbes. Therefore, persistent neurotropic pathogens might play a role in microglia activation in the brain of genetically susceptible elderly and contribute to neurodegenerative processes $[4,5]$.

The amyloid- $\beta(A \beta)$ peptide, which is associated with neurodegenerative processes of $A D$, showed antimicrobial activity against eight common and clinically relevant microorganisms [6]. A $\beta$ peptide 
shares several chemical and biological characteristics of antimicrobial peptides (AMPs), which are components of the innate immune system [6]. Moreover, A $\beta$ peptide showed a protective activity against in vitro infection by the neurotropic virus, herpes simplex virus 1 (HSV-1) [7]. This observation reinforces the notion that persistent and latent herpes virus infections may lead to $A \beta$ overproduction that, in turn, contributes to amyloid plaque formation [7].

Recent findings have confirmed a causative role of viruses of the herpes family in AD [8] and the relationship between human herpes virus 6 (HHV-6) and 7 (HHV-7) DNA abundance and expression of amyloid precursor protein modulators along with induction of other several genes previously found associate with AD risk.

We previously suggested that the concomitant presence of a set of single nucleotide polymorphisms (SNPs) associated with AD might result in a genetic signature predisposing to AD via complex and diverse mechanisms, each contributing to modulate individual susceptibility to herpes virus infection [5]. According to this view, efficient immune response is mandatory to preserve brain structure and functioning during aging, and chronic brain infections might play a pathogenic role in the clinical progression of sporadic AD in the elderly with declining immune efficiency [4].

Data regarding the efficiency of human brain immune responses in AD is scanty, and in the present paper, we investigate the brain expression of a selected set of genes belonging to the innate immunity and involved in antivirus defense, such as interferons.

Different members of the Interferon (IFN) family play a pivotal role in the human anti-viral defenses $[9,10]$. IFNs can be produced by several cell types and primarily act as antiviral and immune-modulatory cytokines [9-11]. IFN- $\alpha / \beta$ or type I IFN and IFN- $\lambda$ or type III IFN bind distinct receptors. However, they regulate the same sets of genes and show similar biological activities [10-13].

IFN- $\lambda$ is a recently discovered group of defensive molecules comprising several members such as IFN- $\lambda 1$, IFN- $\lambda 2$, and IFN- $\lambda 3$, also known as IL29, IL28A, and IL28B, respectively [13,14]. An IFN- $\lambda 4$ type has also been described $[15,16]$. Up-regulation of IFN- $\lambda$ transcription has been shown to depend on the same stimuli, sensors, and signal transduction pathways, as those involved in type I IFN production [11].

In the mouse brain, IFN- $\alpha / \beta$ was readily produced after infection with various viral RNAs, whereas IFN- $\lambda$ expression remained lower [17].

IFNs expression is regulated by a family of transcription factors named interferon regulatory factors (IRFs), and they show relevant roles in brain antiviral defenses [18]. In fact, IRF7 and IRF9 share different functions, including host defense, cell growth, apoptosis, and immune cell differentiation [19].

Mediator complex (MED) 23 is an anti-viral component of the mediator complex and regulates the transcription of nearly all RNA polymerase II-dependent genes, which in turn up-regulates IFN- $\lambda$ by interacting with IRF7 [20].

IRF7 was originally identified in the context of Epstein-Barr virus (EBV) infection and has since emerged as the crucial regulator of type I IFNs after activation by pathogen recognition receptors [21].

Type I IFN induction is mainly regulated by IRF3 and IRF7. IRF3 is expressed constitutively, whereas IRF7 is an IFN-stimulated gene, often induced during late phases of virus infection. Therefore, the IFNs induced IRF7 response and IRF7 activation by viral infection provide a positive feedback for further IFNs production. Moreover, both IRF3 and IRF7 regulated the IFN- $\lambda 1$ gene expression, whereas IRF7 has been shown the major regulator of IFN- $\lambda 2 / 3$ genes [22].

Our recent findings showed that SNPs in genes regulating antiviral responses are differentially distributed in AD and influence a differential blood positivity to EBV and HHV-6 in the elderly [23]. Moreover, risk alleles were increased in the elderly progressing to AD [23]. These findings suggested that individual genetic background might play a role in the progression of cognitive impairment by influencing the efficiency of immune responses to persistent viruses.

Knowledge regarding the efficiency of human brain immune responses against bacteria and viruses during aging and $\mathrm{AD}$ is limited. 
In the present study, the mRNA expression of genes involved in antimicrobial responses, such as IRF7, MED23, IL28B or IFN- $\lambda 3$, and IFN- $\alpha$, in hippocampus and temporal cortex specimens from human controls and AD patients was studied. Moreover, the influence of apolipoprotein (APOE) $\varepsilon 4$, IRF7, MED23, and IL28B gene polymorphisms upon mRNA levels of IRF7, MED23, IL28B, and IFN- $\alpha$ genes was also analyzed.

Our findings showed that impaired mRNA levels of IRF7, MED23, IL28B, and IFN- $\alpha$ were present in AD hippocampus and temporal cortex samples. APOE $\varepsilon 4$ and IRF7 A alleles negatively affected mRNA levels in AD hippocampus.

Antimicrobial defense mechanisms of innate immunity appear to be impaired in the AD brain, and such alterations might contribute to neurodegeneration.

\section{Results}

Demographic and clinical features, such as age, gender, clinical diagnosis, disease duration (DD), post-mortem interval (PMI), brain weight, cause of death, and brain area, of patients with AD have been reported in Table 1. AD neuropathological diagnosis, Braak and Thal amyloid deposition scores have been summarized in Table 2 .

Table 1. Demographic and clinical features of demented patients.

\begin{tabular}{|c|c|c|c|c|c|c|c|c|}
\hline ID & $\begin{array}{l}\text { Age } \\
\text { (Years) }\end{array}$ & Gender & $\begin{array}{l}\text { Clinical } \\
\text { Diagnosis }\end{array}$ & DD & PMI (h) & BW (gr) & Cause of Death & Brain Area \\
\hline 1 & 78 & $\mathrm{~F}$ & MID & 7 & 4.35 & 1043 & Pneumonia, cachexia, decubitus & Hip; Temp \\
\hline 2 & 78 & $\mathrm{~F}$ & $\mathrm{AD}$ & 10 & 4.50 & 1105 & Gastrointestinal bleeding & Hip; Temp \\
\hline 3 & 81 & M & $\mathrm{AD}$ & 5 & 4.50 & 1253 & $\begin{array}{l}\text { Probable CVA and sepsis with } \\
\text { unknown underlying disease }\end{array}$ & Hip \\
\hline 4 & 95 & $\mathrm{~F}$ & $\begin{array}{l}\text { MID possibly } \\
\text { mixed with } A D\end{array}$ & 7 & 3.40 & 1032 & Aspiration pneumonia & Hip \\
\hline 5 & 86 & M & MID & 6 & 3.40 & 1206 & $\begin{array}{l}\text { Metabolic disturbances, dehydration, } \\
\text { metastasized prostate carcinoma }\end{array}$ & Hip; Temp \\
\hline 6 & 84 & F & MID & na & 3.40 & 1109 & Dehydration, cachexia & Hip; Temp \\
\hline 7 & 92 & F & VD & 3 & 3.40 & 1115 & Bleeding gastric ulcer & Hip \\
\hline 8 & 73 & $\mathrm{~F}$ & $\mathrm{AD}$ & 12 & 3.40 & 1082 & Sepsis, cachexia & Hip \\
\hline 9 & 67 & $\mathrm{~F}$ & presenile AD & 15 & 3.40 & 945 & Cachexia & Hip; Temp \\
\hline 10 & 93 & M & $\mathrm{AD}$ & 1 & 3.40 & 1210 & na & Hip \\
\hline 11 & 93 & M & MID & 9 & 3.40 & 1220 & Cardiac failure caused by pneumonia & Hip \\
\hline 12 & 69 & M & na & na & 3.40 & 1241 & Dehydration, cachexia & Hip \\
\hline 13 & 89 & $\mathrm{~F}$ & $\mathrm{AD}$ & 11 & 3.40 & 1211 & na & Hip \\
\hline 14 & 84 & $\mathrm{~F}$ & $\mathrm{AD}$ & na & 3.40 & 1098 & Dehydration & Hip \\
\hline 15 & 91 & F & $\mathrm{AD}$ & 5 & 3.40 & 1101 & $\begin{array}{l}\text { Dehydration, cachexia, and probable } \\
\text { CVA }\end{array}$ & Hip; Temp \\
\hline 16 & 93 & F & $\mathrm{AD}$ & 4 & 2.30 & 1045 & Cachexia & Hip; Temp \\
\hline 17 & 86 & F & $\mathrm{AD}$ & 10 & 5.05 & 998 & $\begin{array}{l}\text { Uncontrolled anti-coagulation in } \\
\text { combination with general } \\
\text { deterioration after hip prosthesis }\end{array}$ & Hip \\
\hline 18 & 94 & F & VD after CVA & 6 & 5.05 & 1170 & Cachexia and dehydration, decubitus & Hip \\
\hline 19 & 75 & F & $\mathrm{AD}$ & 9 & 6.00 & 1129 & Dehydration & Hip \\
\hline 20 & 89 & $\mathrm{~F}$ & VD & 19 & 4.30 & 1185 & Pneumonia & Hip; Temp \\
\hline 21 & 74 & M & $\mathrm{AD}$ & 2 & 5.35 & 1380 & $\begin{array}{l}\text { Anemia, hepatic dysfunction, } \\
\text { extensive lymphadenopathy by M. } \\
\text { Kimura }\end{array}$ & Hip \\
\hline 22 & 75 & $\mathrm{~F}$ & $\mathrm{AD}$ & 6 & 15.0 & 1230 & Cardiac arrest & Hip \\
\hline 23 & 94 & F & $\mathrm{AD}$ & 6 & 8.05 & 1053 & Cachexia & Hip \\
\hline 24 & 90 & F & $\mathrm{AD}$ & 6 & 5.40 & 1100 & CVA, advanced AD & Hip \\
\hline 25 & 88 & F & na & 1 & 6.45 & 1170 & Natural death & Hip \\
\hline 26 & 66 & $\mathrm{~F}$ & $\mathrm{AD}$ & 6 & 6.30 & 1190 & $\begin{array}{l}\text { Acute heart failure by advanced } \\
\text { dementia syndrome }\end{array}$ & Hip \\
\hline 27 & 82 & $\mathrm{~F}$ & VD & 6 & 5.55 & 1225 & $\begin{array}{c}\text { Cardiac arrest with dehydration after } \\
\text { MI }\end{array}$ & Hip \\
\hline 28 & 99 & $\mathrm{~F}$ & $\mathrm{AD}$ & 5 & 3.30 & 1150 & Airway infection & Hip \\
\hline 29 & 60 & M & $\begin{array}{l}\text { AD possibly of } \\
\text { Lewy Body type }\end{array}$ & 3 & 6.15 & 1241 & $\begin{array}{l}\text { Cachexia and dehydration by } \\
\text { dementia syndrome }\end{array}$ & Hip; Temp \\
\hline 30 & 81 & F & $\mathrm{AD}$ & 2 & 6.10 & 1295 & $\begin{array}{l}\text { Cachexia and dehydration by } \\
\text { dementia syndrome }\end{array}$ & Temp \\
\hline 31 & 57 & M & presenile AD & 6 & 3.50 & 1055 & Aspiration pneumonia & Temp \\
\hline 32 & 69 & M & $\mathrm{VD}, \mathrm{CI}$ & 3 & 7.10 & 1173 & Aspiration pneumonia & Temp \\
\hline 33 & 86 & M & $\mathrm{AD}$ & 6 & 6.15 & 1331 & $\begin{array}{l}\text { Possible cardiac arrest after } \\
\text { gastroenteritis by } \mathrm{AD}\end{array}$ & Temp \\
\hline 34 & 92 & $\mathrm{~F}$ & $\mathrm{AD}$ & 5 & 3.25 & 1105 & Probable CVA & Temp \\
\hline
\end{tabular}


Table 1. Cont

\begin{tabular}{|c|c|c|c|c|c|c|c|c|}
\hline ID & $\begin{array}{c}\text { Age } \\
\text { (Years) }\end{array}$ & Gender & $\begin{array}{l}\text { Clinical } \\
\text { Diagnosis }\end{array}$ & DD & PMI (h) & BW (gr) & Cause of Death & Brain Area \\
\hline 35 & 88 & F & $\mathrm{AD}$ & 12 & 12.15 & 935 & Cachexia and decubitus & Temp \\
\hline 36 & 85 & $\mathrm{~F}$ & MID & 5 & 4.45 & 1310 & Shock due to acute abdomen & Temp \\
\hline 37 & 94 & $\mathrm{~F}$ & na & na & 5.00 & 1410 & Double side pneumonia & Temp \\
\hline 38 & 80 & M & na & na & 4.00 & 1328 & Unknown & Temp \\
\hline 39 & 85 & M & $\begin{array}{l}\text { AD possibly in } \\
\text { combination with } \\
\text { MID }\end{array}$ & 5 & 4.25 & 1458 & $\begin{array}{c}\text { Sudden death (suspected } \\
\text { heart-failure) }\end{array}$ & Temp \\
\hline
\end{tabular}

Abbreviations: DD, Disease Duration; PMI, Post-mortem Interval; BW, Brain Weight; F, female; M, male; MID, Multi-Infarct Dementia; AD, Alzheimer's Disease; VD, Vascular Dementia; CI, Cognitive Impairment; CVA, Cerebrovascular Accident; MI, Myocardial Infarction; Hip, hippocampus; Temp, mid temporal cortex; na, not applicable.

Table 2. Alzheimer's disease (AD) neuropathological features.

\begin{tabular}{|c|c|c|c|}
\hline ID & Pathological Diagnosis & Grade (Braak, NTF) & Grade (Thal, $A \beta$ ) \\
\hline 1 & $\mathrm{AD}$ & 5 & $\mathrm{C}$ \\
\hline 2 & $\mathrm{AD}$ & 5 & $\mathrm{C}$ \\
\hline 3 & $\mathrm{AD}$ & 4 & $\mathrm{C}$ \\
\hline 4 & $\mathrm{AD} ;$ meningioma & 4 & $\mathrm{C}$ \\
\hline 5 & $\mathrm{AD}$ & 3 & $\mathrm{~A} / \mathrm{B}$ \\
\hline 6 & $\mathrm{AD}$ & 5 & $\mathrm{C}$ \\
\hline 7 & AD; infarction & 4 & $\mathrm{C}$ \\
\hline 8 & $\mathrm{AD}$ & 5 & $\mathrm{C}$ \\
\hline 9 & $\mathrm{AD}$ & 6 & C \\
\hline 10 & $\mathrm{AD}$ & 5 & $\mathrm{C}$ \\
\hline 11 & $\mathrm{AD} ; \mathrm{caa} ; \mathrm{arg}$ & 4 & C \\
\hline 12 & $\mathrm{AD}$ & 6 & C \\
\hline 13 & $\mathrm{AD}$ & 5 & $\mathrm{C}$ \\
\hline 14 & AD; infarction & 5 & $\mathrm{C}$ \\
\hline 15 & $\mathrm{AD}$ & 4 & $\mathrm{C}$ \\
\hline 16 & $\mathrm{AD}$ & 4 & $\mathrm{C}$ \\
\hline 17 & $\mathrm{AD}$ & 4 & $\mathrm{C}$ \\
\hline 18 & AD; infarction & 4 & $\mathrm{C}$ \\
\hline 19 & $\mathrm{AD} ;$ саa & 5 & C \\
\hline 20 & $\mathrm{AD}$ & 6 & $\mathrm{C}$ \\
\hline 21 & $\mathrm{AD}$ & 6 & $\mathrm{C}$ \\
\hline 22 & $\mathrm{AD}$ & 5 & $\mathrm{C}$ \\
\hline 23 & $\mathrm{AD}$ & 4 & $\mathrm{C}$ \\
\hline 24 & AD; infarction & 6 & $\mathrm{C}$ \\
\hline 25 & $\mathrm{AD}$ & 5 & C \\
\hline 26 & $\mathrm{AD}$ & 5 & C \\
\hline 27 & $\mathrm{AD}$ & 4 & $\mathrm{C}$ \\
\hline 28 & $\mathrm{AD}$ & 4 & $\mathrm{C}$ \\
\hline 29 & $\mathrm{AD}$ & 6 & $\mathrm{C}$ \\
\hline 30 & $\mathrm{AD}$ & 5 & $\mathrm{C}$ \\
\hline 31 & $\mathrm{AD}$ & 6 & $\mathrm{C}$ \\
\hline 32 & AD; infarction & 5 & B \\
\hline 33 & $\mathrm{AD}$ & 5 & C \\
\hline 34 & $\mathrm{AD}$; ischemia & 5 & $\mathrm{C}$ \\
\hline 35 & $\mathrm{AD}$ & 4 & $\mathrm{C}$ \\
\hline 36 & $\mathrm{AD}$ & 5 & $\mathrm{C}$ \\
\hline 37 & $\mathrm{AD}$ & 4 & $\mathrm{C}$ \\
\hline 38 & $\mathrm{AD}$ & 4 & C \\
\hline 39 & $\mathrm{AD}$ & 5 & $\mathrm{~B} / \mathrm{C}$ \\
\hline
\end{tabular}

Abbreviations: caa = congophilic angiopathy $\arg =$ argyriphilic grain disease .

Levels of IRF7, MED23, IL28B, and IFN- $\alpha$ mRNA in AD brain hippocampus and temporal samples are reported in Figure 1. The majority of AD brains showed decreased hippocampus mRNA levels of IRF7 ( $n=28)$, MED23 $(n=20)$, IL28B $(n=21)$, and IFN- $\alpha(n=19)$, whilst a small AD group had increased mRNA levels of MED23 ( $n=11), \operatorname{IL28B}(n=12)$, and IFN- $\alpha(n=9)$. 
A similar mRNA expression pattern was detected in AD temporal cortex samples, since a larger AD group showed downregulation of IRF7, MED23, IL28B, and IFN- $\alpha$ genes (Figure 1). A minority of AD showed normal or slightly increased mRNA levels of the above immune factors (Figure 1).

\section{Hippocampus}

A

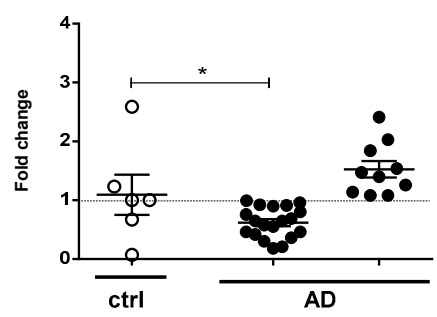

C

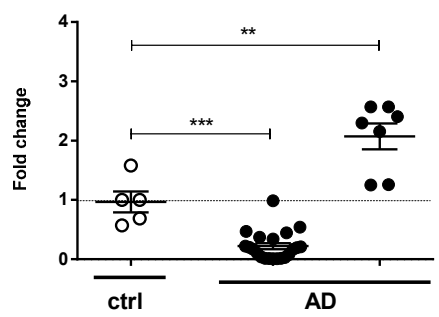

B

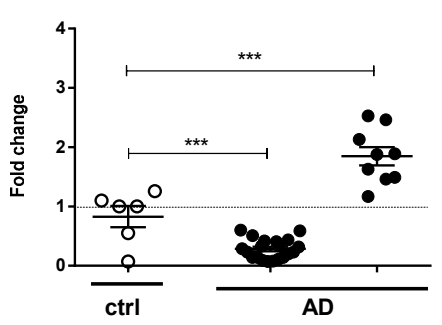

D

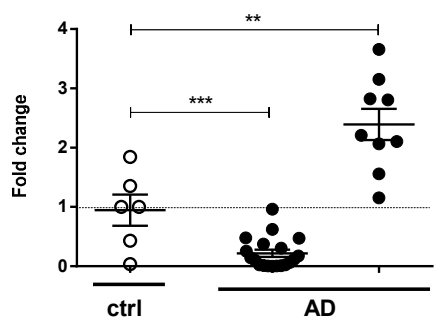

\section{Temporal cortex}

E

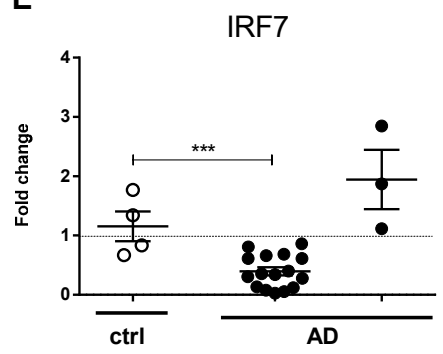

G

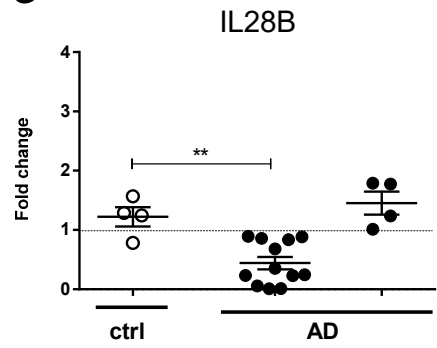

F

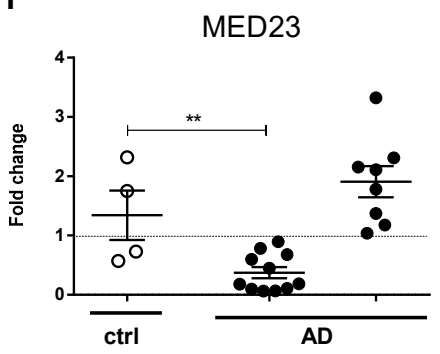

H

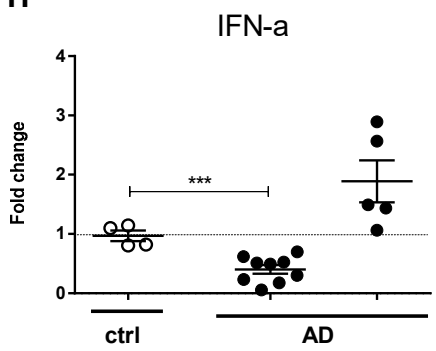

Figure 1. Hippocampal and temporal cortex differential expression of antiviral response genes in Alzheimer's disease (AD) patients and control subjects. Fold change (q-PCR $2^{-\Delta \Delta C t}$ method) of IRF7 $(\mathbf{A}, \mathbf{E}), \operatorname{MED} 23(\mathbf{B}, \mathbf{F})$, IL28B (C,G), IFN- $\alpha(\mathbf{D}, \mathbf{H})$ normalized to two reference genes (CYC1 and EIF4A2) and relative to control healthy subjects (ctrl), in hippocampus (A-D) and temporal cortex (E-H) of patients with clinical and neurological defined diagnosis of AD. Values are given as fold change \pm SEM. ${ }^{*} p<0.05 ;{ }^{* *} p<0.01$; ${ }^{* * *} p<0.001$ (unpaired $t$-test). 
Brain samples were also genotyped for APOE $\varepsilon$ polymorphism and gene variations of IRF7, MED23, and IL28B. The presence of APOE $\varepsilon 4$ allele was associated with decreased mRNA levels of MED23, IL28B, and IFN- $\alpha$ in AD hippocampus samples and of MED23 in AD temporal cortex samples, as shown in Figure 2.

\section{Hippocampus}

A

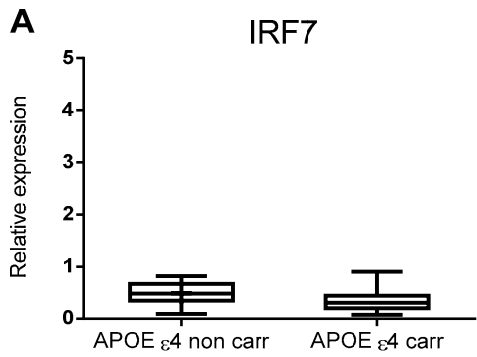

C

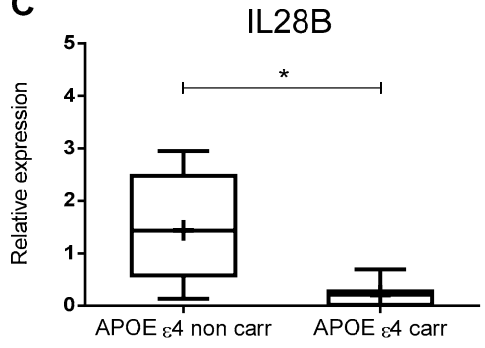

B

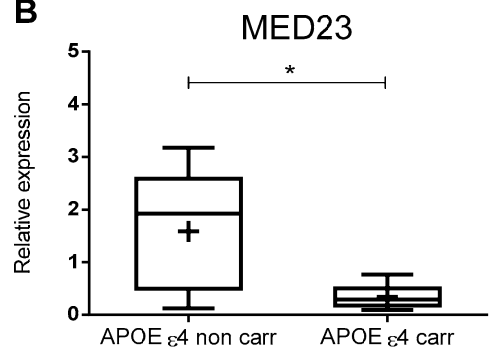

D

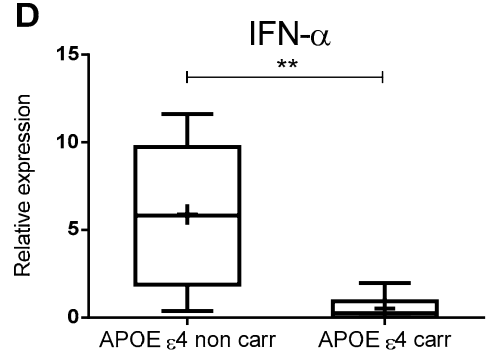

\section{Temporal cortex}

$\mathrm{E}$

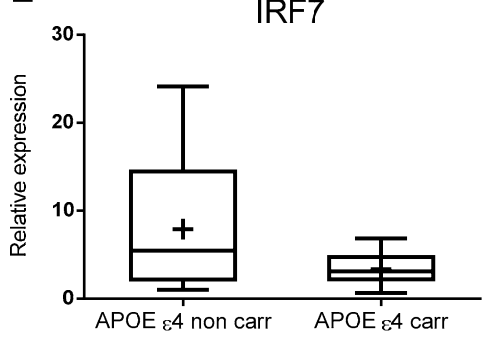

G

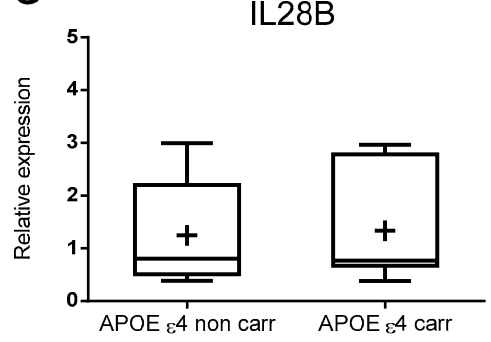

$\mathbf{F}$

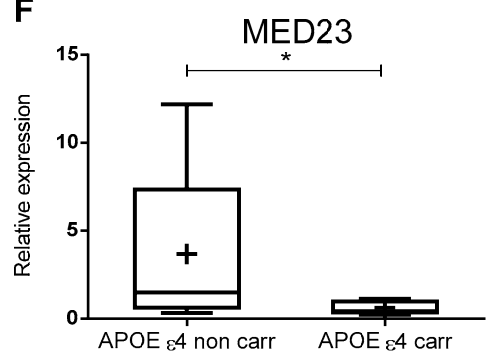

H

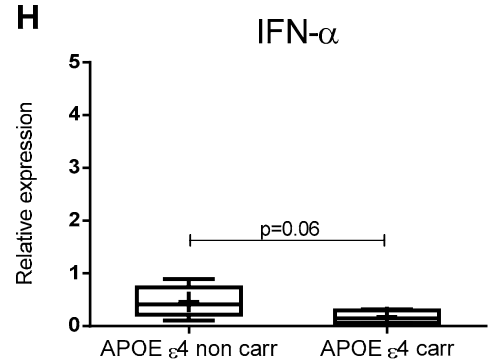

Figure 2. Effect of APOE $\varepsilon 4$ allele on antiviral immune gene expression of AD patients. q-PCR data showing relative expression ( $2^{-\triangle \mathrm{Ct}}$ values using CYC1 and EIF4A2 as reference genes) of IRF7 (A,E), MED23 (B,F), IL28B (C,G), IFN- $\alpha(\mathbf{D}, \mathbf{H})$ in hippocampus (A-D) and temporal cortex (E-H) of AD patients grouped in APOE $\varepsilon 4$ noncarrier/or APOE $\varepsilon 4$ carrier. Data from each group are shown as a box and whiskers plot with the ends of the whiskers represent the minimum and maximum data values, the horizontal line represents the median, and the " + " represents the mean relative expression values. ${ }^{*} p<0.05^{* *} p<0.01$ (unpaired t-test). 
IRF7 gene polymorphism affected IRF7, MED23, IL28B, and IFN- $\alpha$ mRNA levels, and A allele carriers showed significantly decreased levels of the four immune factors in AD hippocampus samples (Figure 3).

\section{Hippocampus}
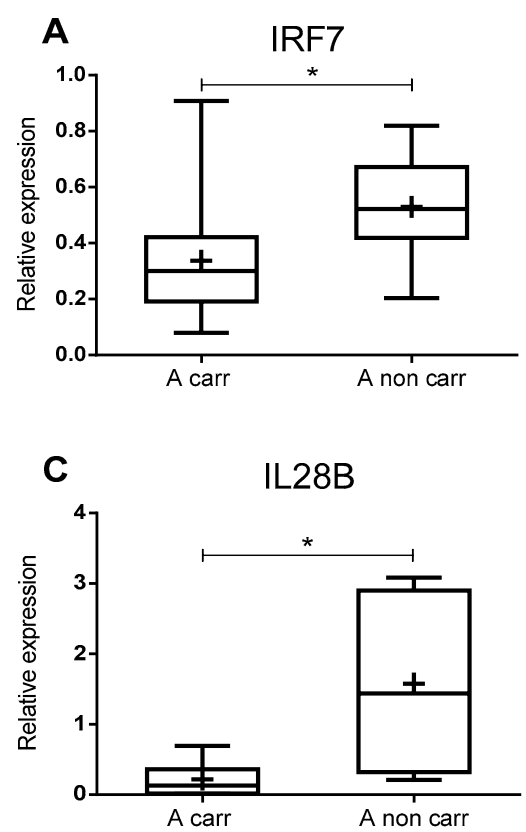
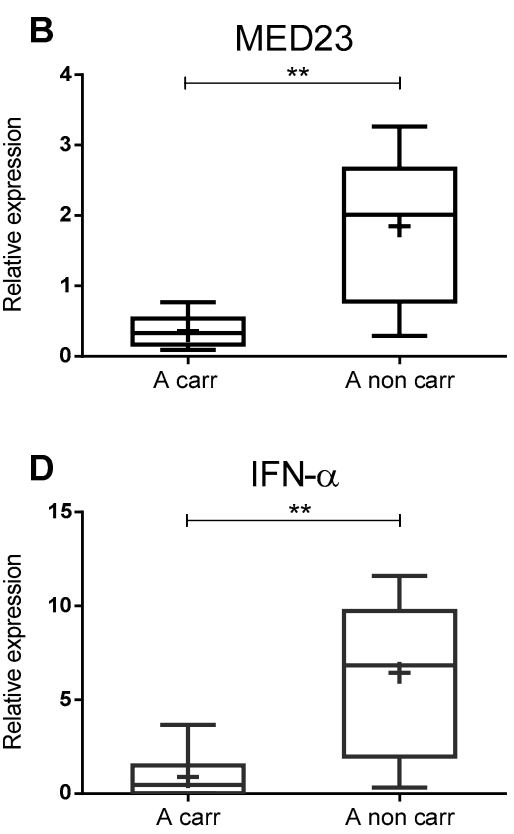

Figure 3. Effect of IRF7 (rs6598008) SNP on antiviral immune gene expression of AD patients. qPCR data showing relative expression ( $2^{-\triangle \mathrm{Ct}}$ values using CYC1 and EIF4A2 as reference genes) of IRF7 (A), MED23 (B), IL28B (C), IFN- $\alpha$ (D) in the hippocampus of AD patients grouped in A carrier/or A noncarrier. Data from each group are shown as a box and whiskers plot with the ends of the whiskers represent the minimum and maximum data values, the horizontal line represents the median, and the " + " represents the mean relative expression values. ${ }^{*} p<0.05^{* *} p<0.01$ (unpaired $t$-test).

No statistically significant difference in mRNA levels of IRF7, MED23, IL28B, and IFN- $\alpha$ from temporal cortex samples between IRF7 A carriers and A noncarriers was observed (data not shown).

The presence of MED23, IL28B, IFN- $\alpha$ gene polymorphisms was not associated with mRNA levels of the four immune factors in both hippocampus and temporal cortex specimens (data not shown).

No relationship between IRF7, MED23, IL28B, and IFN- $\alpha$ mRNA levels and Braak and Braak or Thal scores, duration of the disease, and brain weight was found (data not shown).

\section{Discussion}

The efficiency of immune responses declines with advancing age [24,25], and old age is a major risk factor for AD. However, the role of the immune system in the disease is still unclear. Genome-wide association studies performed in $\mathrm{AD}$ reported that several genes with immune regulatory functions were associated with differential risk of the disease [26,27]. However, a more defined role of genes regulating innate immunity with the pathogenesis and clinical history of $\mathrm{AD}$ remains to be assessed.

Infections by pathogens, such as the Herpes virus, have been suggested to play a role in the clinical progression of the disease [28]. It is known that even in healthy young persons, the immune system never completely eradicates these pathogens. In the elderly, repeated cycles of activation and latency, along with infective agent persistence, may further impair immune responses and accelerate the senescence of the immune system [2,25]. Moreover, herpes viruses, which are neurotropic, might directly infect and damage selected brain areas in genetically susceptible elderly, contributing to neurodegenerative mechanisms [5], and herpes DNA has been indeed found in AD brains [4,8,25]. 
Recent findings confirm and extend the association of herpes virus infection with neurodegeneration and $\operatorname{AD}[8,29,30]$. Other pathogens have been implicated in the clinical history of $\mathrm{AD}$ [31], and chronic infections are emerging risk factors for the disease [32].

Recent data showed that amyloid-A $\beta$ peptide protected against microbial infection in AD animal models [33]. For instance, $A \beta$ oligomerization was necessary for its antimicrobial activity, and brain infection of 5XFAD mice by Salmonella Typhimurium bacterium resulted in an amyloid deposition surrounding the invading bacteria [33], and $A \beta$ peptide has been related to immune defensive mechanisms of the human brain [34]. These data are compatible with the notion that the amyloid-A $\beta$ peptide might be a component of the innate immunity against brain pathogens and virus brain chronic infection may induce its production.

Findings in the present article showed that gene expression of antimicrobial defense factors, such as IRF7, MED23, IL28B, and IFN- $\alpha$, was impaired in AD brains.

Most AD brains showed decreased mRNA levels of these defensive factors, while a minority of $A D$ patients had increased levels. Differential expression patterns might represent different AD clinical stages. Brains overexpressing the immune factors might actively respond to an active regional infection or tissue insult. After a partially successful immune response, a latent viral phase is induced, and these factors are downregulated. Such a decrement would decrease the concomitant activation of microglia and astrocyte, downregulate neuroinflammation, and mitigate neuronal damages. In other words, we suggest that different expression patterns of immune factors and cytokines may describe different reactivation and latency cycles of infectious agents.

Increased mRNA levels of MED 23, IL28B, and IFN- $\alpha$ were found only in the AD hippocampus, and our data suggest that different brain regions appear to be differentially involved in these chronic inflammatory responses. Replicating neurons in the hippocampus cortex [35] appear to be more susceptible to virus infections or microbial products/toxins. Therefore, persistent inflammation may induce accelerated neurodegenerative mechanisms in this brain area.

Possible regulatory mechanisms of the innate immunity genes upon amyloid-A $\beta$ peptide expression in normal or AD brains have been poorly explored. However, it cannot be excluded that amyloid-A $\beta$ peptide might function as an emergency defensive mechanism and compensate the impaired efficiency of other specialized immune defensive genes in the aging brain.

Here, we showed that MED23, IL28B, and IFN- $\alpha$ mRNA hippocampus levels in AD APOE $\varepsilon 4$ carriers were further decreased. The temporal cortex from AD APOE $\varepsilon 4$ carriers also showed the lowest values of MED23 and IFN- $\alpha$ mRNA levels.

It is known that APOE affects immunity since increased systemic pro-inflammatory states and altered immune responses have been found in APOE deficient mice [36,37]. Therefore, at least part of the increasing AD risk effect of the APOE $\varepsilon 4$ allele might be mediated by a negative influence on the brain's immune efficiency.

Our data show that IRF7 allele A carrier status was associated with decreased levels of IRF7, MED23, IL28B, and IFN- $\alpha$ expression in the AD hippocampus. These findings reinforce the notion that individual genetic makeup affects brain immune efficiency.

Findings regarding IFN and brain functions are scanty. However, transgenic mice chronically overexpressing astrocyte IFN- $\alpha$ developed a progressive inflammatory encephalopathy and neurodegeneration [38]. Moreover, IRF7 deficient mice produced elevated levels of CXCL13 after virus infection and showed impaired regulation of microglia activity [39].

It is interesting to note that type I-IFNs also play a critical role in regulating tissue homeostasis and regeneration. Insufficient resilience, defined as impaired repair and regeneration of host tissues, rather than inefficient infectious agent clearance, may induce chronic neuroinflammation [40], and inefficient brain resilience over the years might contribute to neurodegeneration in preclinical and clinical AD.

Our results are in accordance with different genetic investigations from genome-wide association studies showing an association of several immune regulatory genes with AD pathogenesis [27]. In fact, subsequent complementary statistics and bio-informatic approaches showed that several single-gene 
polymorphisms in IFN genes increased AD risk [41]. Results from our investigation further support the relevance of IFN family genes in AD.

Our findings from post-mortem brain samples, however, do not rule out that the impaired expression of these genes might be a late event in the clinical progression of the disease, since, most AD patients showed high Braak and Thal scores.

Protein levels of these immune factors in AD brains were not measured, since many variables, such as post-mortem latency, disease stage or duration, may increase case protein variability, and this is a limitation of our investigation. Moreover, astrocyte or microglia classical neuropathological markers of activation were not investigated. Therefore, the contribution of these cell populations to brain mRNA levels of IRF7, MED23, IL28B, and IFN- $\alpha$ remains to be explored. However, astrogliosis, along with a decrease of neuron number, are classical neuropathology hallmarks of the AD brain [42] and increased or decreased mRNA levels might also be related to the brain area balance of these different cell populations.

Our data showed that different factors, such as brain area locations and individual genetic makeup, along with other undetermined factors, affect gene expression of innate immunity components and indirectly support the notion that impaired innate immune responses against brain insults, such as viruses, bacteria, fungi or their products, might accelerate neurodegenerative mechanisms in the elderly. A recent book elaborates in detail the role of infective agents in AD [43], and the present investigation agrees with the notion of infection association with AD.

In conclusion, the maintenance of efficient immune responses during aging might slow down neurodegenerative mechanisms associated with senile dementia and affect both the prevalence and incidence of AD. Further investigations regarding infections, immune defensive mechanisms, and AD progression might open new ways for AD prevention and therapy.

\section{Materials and Methods}

\subsection{Post-Mortem Human Brain Tissue}

Post-mortem brain tissues of AD patients and age-matched nondemented controls (ctrl) were obtained from the Netherlands Brain Bank (NBB; Amsterdam, The Netherlands), in accordance with rules and regulations of the Ethical Code from BrainNet Europe. Patients or their next of kin gave written informed consent to NBB for brain autopsy and use of tissue and clinical information for research purposes. This study was approved by the NBB scientific committee and conditions for transferring and using brain samples regulated by the Material Transfer Agreement (MTA). Neuropathological evaluation and $\mathrm{AD}$ pathology staging followed Braak and Braak criteria for neurofibrillary tangles (NFTs) and Thal criteria for amyloid deposition [44,45].

AD brain tissues were stored in liquid nitrogen, and $20 \mu \mathrm{m}$ thick slices of the hippocampus and temporal cortex were cut at $-20^{\circ} \mathrm{C}$, collected in RNAse free Eppendorf vials, and stored at $-80^{\circ} \mathrm{C}$ for the following molecular analyses.

Twenty-nine AD hippocampus brain samples, nineteen AD temporal cortex brain samples, six hippocampus, and four temporal cortex samples from ctrl cases were included in this study. The final selection was based on the availability of DNA and RNA samples of good quantity and quality.

\subsection{Genomic DNA Isolation}

Genomic DNA was obtained from frozen samples and purified according to the Phenol:Chloroform:Isoamyl Alcohol (25:24:1) extraction's protocol (Sigma-Aldrich, St. Louis, MO, USA) after overnight incubation with proteinase $\mathrm{K} 10 \mathrm{mg} / \mathrm{mL}$ (Roche, Basel, Switzerland) and ATL buffer (Qiagen, Hilden, Germany). Absorbance measurements were made on a NanoDrop 1000 (Thermo Scientific, Wilmington, DE, USA), and the ratio of absorbance at $260 \mathrm{~nm}$ and $280 \mathrm{~nm}$ was used to assess the purity of DNA samples, further stored at $-80^{\circ} \mathrm{C}$. 


\subsection{RNA Isolation}

RNA extraction from frozen hemi-brain hippocampus or temporal cortex samples was performed using an RNA-Bee kit (AMSBIO, Cambridge, MA, USA) according to the manufacturer's instructions. Total RNA was purified according to phenol-chloroform standard extraction after overnight incubation with proteinase K. Absorbance measurements were made on a NanoDrop 1000 (Thermo Scientific, Wilmington, DE, USA), and the ratio of absorbance at $260 \mathrm{~nm}$ and $280 \mathrm{~nm}$ was used to assess the purity of RNA samples, further stored at $-80^{\circ} \mathrm{C}$.

\subsection{Quantitative Reverse-Transcription Polymerase Chain Reaction}

RNA (50 ng) was converted to cDNA retro transcribed using the iScript ${ }^{\mathrm{TM}}$ cDNA Synthesis Kit (Bio-Rad, Hercules, CA, USA) following the manufacturer's instructions. PrimerPCR ${ }^{\mathrm{TM}}$ assay for real-time PCR gene expression analysis was performed using SsoAdvanced ${ }^{\mathrm{TM}}$ Universal SYBR $^{\circledR}$ Green Supermix (Bio-Rad, Hercules, CA, USA) according to the manufacturer's instructions. Bio-Rad pre-validated primer pairs for target genes IRF7 (qHsaCED0007783), MED23 (qHsaCID0007348), IL28B (qHsaCED0038284), IFN- $\alpha$ (qHsaCED0037471), and for two reference genes were used. CYC1 (qHsaCED0047348) and EIF4A2 (qHsaCED0023870) were selected as reference genes for normalization, as suggested by Penna and colleagues [46].

Quantitative PCR assay (q-PCR) for gene expression analysis was realized in a CFX96 Touch $^{\mathrm{TM}}$ System instrument (Bio-Rad, Hercules, CA, USA), and all reactions were run in triplicate in 96-well optical plates. q-PCR data were analyzed by Bio-Rad CFX Manager ${ }^{\mathrm{TM}}$ Software (version 3.1, Bio-Rad, Hercules, CA, USA). Using the $2-{ }^{\Delta \Delta \mathrm{Ct}}$ method [47], the gene expression data were computed as the gene expression fold change after normalization to the two reference genes (CYC1 and EIF4A2).

\subsection{SNPs Detection}

TaqMan ${ }^{\circledR}$ SNP Genotyping Assay (Applied Biosystems, Foster City, CA, USA) was used for genotyping $\mathrm{AD}$ patients according to the manufacturer's instructions. It included an unlabeled PCR primer pair to detect specific targeted SNP and two different Taqman ${ }^{\circledR}$ probes for detecting two SNP alleles: one probe was labeled with VIC ${ }^{\circledR}$ dye and the other one with 6-FAM ${ }^{\circledR}$ dye. Allelic discrimination was performed by probe signal intensity from PCR (RT-PCR) using a CFX96 Touch ${ }^{\mathrm{TM}}$ System instrument (Bio-Rad, Hercules, CA, USA).

APOE $\varepsilon$ allele (rs429358 and rs7412) was assessed by RT-PCR using Taqman ${ }^{\circledR}$ probes according to the manufacturer's instructions. The upstream variant of IRF7 (rs6598008 A/G), MED23 (rs3756784 T/G), and IL28B (rs12979860 C/T) genes were also analyzed by RT-PCR using Taqman ${ }^{\circledR}$ probes according to the manufacturer's instructions.

\subsection{Statistical Analysis}

Statistical analysis was performed using the Statistical Package for the Social Sciences (version 22.0; SPSS Inc, Chicago, IL, USA) and two-sided $p$-values are presented.

After careful quality control of the normalized data, a generalized linear model analysis (ANOVA) followed by Bonferroni post-test or unpaired $t$-test was used to analyzed differences in gene expression data between groups.

\section{Conclusions}

Our data indirectly support the notion that impaired innate immune responses against brain insults induced by microorganism infection might accelerate neurodegenerative mechanisms in the elderly.

Maintenance of efficient immune responses in the elderly might slow down neurodegenerative mechanisms associated with age-related cognitive decline and affect the prevalence and incidence of AD. 
Author Contributions: Author contributions to this paper: Conceptualization, M.R., E.P., I.C., R.V., and F.L.; Methodology, M.R., E.P., and I.C.; Formal analysis, M.R., E.P., I.C., and R.V.; Investigation, M.R., E.P., I.C., R.V., and F.L.; Resources, R.V. and F.L.; Writing—original draft preparation, M.R., E.P., and F.L.; writing一review and editing, M.R., E.P., R.V., and F.L.; Supervision, M.R., E.P., and F.L.; Funding acquisition, F.L. All authors have read and agreed to the published version of the manuscript.

Funding: Research was supported by the University of Bologna, the Italian Ministry of Research and University, and by the Netherlands Brain Bank.

Acknowledgments: We gratefully thank Marlies Jacobs, Mariska van der Wal, and Elise van Haastert for helping with the retrieval of tissue samples from the liquid nitrogen and for cutting and collecting cryostat sections and Cees Oudejans for the use of the molecular biology infrastructure at Clinical Chemistry VUmc.

Conflicts of Interest: The authors declare no conflict of interest. The funders had no role in the design of the study; in the collection, analyses, or interpretation of data; in the writing of the manuscript, or in the decision to publish the results.

\section{Abbreviations}

$\begin{array}{ll}\text { AD } & \text { Alzheimer's Disease } \\ \text { IRF } & \text { Interferon Regulatory Factor } \\ \text { MED23 } & \text { Mediator Complex 23 } \\ \text { IL } & \text { Interleukin } \\ \text { IFN } & \text { Interferon } \\ \text { APOE } & \text { Apolipoprotein } \\ \text { A } \beta & \text { Amyloid- } \beta \\ \text { AMPs } & \text { Antimicrobial Peptides } \\ \text { HSV-1 } & \text { Herpes Simplex Virus 1 } \\ \text { HHV } & \text { Human Herpes Virus } \\ \text { SNP } & \text { Single Nucleotide Polymorphism } \\ \text { EBV } & \text { Epstein-Barr Virus } \\ \text { DD } & \text { Disease Duration } \\ \text { PMI } & \text { Post-Mortem Interval } \\ \text { CXCL13 } & \text { Chemokine (C-X-C motif) Ligand 13 } \\ \text { NBB } & \text { Netherlands Brain Bank } \\ \text { MTA } & \text { Material Transfer Agreement } \\ \text { NTFs } & \text { NeuroFibrillary Tangles } \\ \text { CYC1 } & \text { Cytochrome C1 } \\ \text { EIF4A2 } & \text { Eukaryotic Initiation Factor 4A2 } \\ \text { q-PCR } & \text { Quantitative PCR assay } \\ \end{array}$

\section{References}

1. Katzman, R. Editorial: The prevalence and malignancy of Alzheimer disease. A major killer. Arch. Neurol. 1976, 33, 217-218. [CrossRef] [PubMed]

2. Pawelec, G.; Derhovanessian, E.; Larbi, A.; Strindhall, J.; Wikby, A. Cytomegalovirus and human immunosenescence. Rev. Med. Virol. 2009, 19, 47-56. [CrossRef] [PubMed]

3. Heppner, F.L.; Ransohoff, R.M.; Becher, B. Immune attack: The role of inflammation in Alzheimer disease. Nat. Rev. Neurosci. 2015, 16, 358-372. [CrossRef]

4. Carbone, I.; Lazzarotto, T.; Ianni, M.; Porcellini, E.; Forti, P.; Masliah, E.; Gabrielli, L.; Licastro, F. Herpes virus in Alzheimer's disease: Relation to progression of the disease. Neurobiol. Aging 2014, 35, 122-129. [CrossRef] [PubMed]

5. Licastro, F.; Carbone, I.; Ianni, M.; Porcellini, E. Gene signature in Alzheimer's disease and environmental factors: The virus chronicle. J. Alzheimers Dis. 2011, 27, 809-817. [CrossRef] [PubMed]

6. Soscia, S.J.; Kirby, J.E.; Washicosky, K.J.; Tucker, S.M.; Ingelsson, M.; Hyman, B.; Burton, M.A.; Goldstein, L.E.; Duong, S.; Tanzi, R.E.; et al. The Alzheimer's disease-associated amyloid beta-protein is an antimicrobial peptide. PLOS ONE 2010, 5, e9505. [CrossRef] 
7. Bourgade, K.; Garneau, H.; Giroux, G.; Le Page, A.Y.; Bocti, C.; Dupuis, G.; Frost, E.H.; Fulop, T.J. beta-Amyloid peptides display protective activity against the human Alzheimer's disease-associated herpes simplex virus-1. Biogerontology 2015, 16, 85-98. [CrossRef]

8. Readhead, B.; Haure-Mirande, J.V.; Funk, C.C.; Richards, M.A.; Shannon, P.; Haroutunian, V.; Sano, M.; Liang, W.S.; Beckmann, N.D.; Price, N.D.; et al. Multiscale Analysis of Independent Alzheimer's Cohorts Finds Disruption of Molecular, Genetic, and Clinical Networks by Human Herpesvirus. Neuron 2018. [CrossRef]

9. Pestka, S. The interferons: 50 years after their discovery, there is much more to learn. J. Biol. Chem. 2007, 282, 20047-20051. [CrossRef]

10. Egli, A.; Santer, D.M.; O'Shea, D.; Tyrrell, D.L.; Houghton, M. The impact of the interferon-lambda family on the innate and adaptive immune response to viral infections. Emerg. Microbes Infect. 2014, 3, e51. [CrossRef]

11. Lazear, H.M.; Nice, T.J.; Diamond, M.S. Interferon-lambda: Immune Functions at Barrier Surfaces and Beyond. Immunity 2015, 43, 15-28. [CrossRef] [PubMed]

12. Hermant, P.; Michiels, T. Interferon-lambda in the context of viral infections: Production, response and therapeutic implications. J. Innate Immun. 2014, 6, 563-574. [CrossRef]

13. Kotenko, S.V. IFN-lambdas. Curr. Opin. Immunol. 2011, 23, 583-590. [CrossRef] [PubMed]

14. Sheppard, P.; Kindsvogel, W.; Xu, W.; Henderson, K.; Schlutsmeyer, S.; Whitmore, T.E.; Kuestner, R.; Garrigues, U.; Birks, C.; Roraback, J.; et al. IL-28, IL-29 and their class II cytokine receptor IL-28R. Nat. Immunol. 2003, 4, 63-68. [CrossRef] [PubMed]

15. Bibert, S.; Roger, T.; Calandra, T.; Bochud, M.; Cerny, A.; Semmo, N.; Duong, F.H.; Gerlach, T.; Malinverni, R.; Moradpour, D.; et al. IL28B expression depends on a novel TT/-G polymorphism which improves HCV clearance prediction. J. Exp. Med. 2013, 210, 1109-1116. [CrossRef] [PubMed]

16. Prokunina-Olsson, L.; Muchmore, B.; Tang, W.; Pfeiffer, R.M.; Park, H.; Dickensheets, H.; Hergott, D.; Porter-Gill, P.; Mumy, A.; Kohaar, I.; et al. A variant upstream of IFNL3 (IL28B) creating a new interferon gene IFNL4 is associated with impaired clearance of hepatitis C virus. Nat. Genet. 2013, 45, 164-171. [CrossRef] [PubMed]

17. Sommereyns, C.; Paul, S.; Staeheli, P.; Michiels, T. IFN-lambda (IFN-lambda) is expressed in a tissue-dependent fashion and primarily acts on epithelial cells in vivo. PLoS Pathog. 2008, 4, e1000017. [CrossRef]

18. Ousman, S.S.; Wang, J.; Campbell, I.L. Differential regulation of interferon regulatory factor (IRF)-7 and IRF-9 gene expression in the central nervous system during viral infection. J. Virol. 2005, 79, 7514-7527. [CrossRef]

19. Khorooshi, R.; Owens, T. Injury-induced type I IFN signaling regulates inflammatory responses in the central nervous system. J. Immunol. 2010, 185, 1258-1264. [CrossRef]

20. Griffiths, S.J.; Koegl, M.; Boutell, C.; Zenner, H.L.; Crump, C.M.; Pica, F.; Gonzalez, O.; Friedel, C.C.; Barry, G.; Martin, K.; et al. A systematic analysis of host factors reveals a Med23-interferon-lambda regulatory axis against herpes simplex virus type 1 replication. PLoS Pathog. 2013, 9, e1003514. [CrossRef]

21. Ning, S.; Pagano, J.S.; Barber, G.N. IRF7: Activation, regulation, modification and function. Genes Immun. 2011, 12, 399-414. [CrossRef] [PubMed]

22. Osterlund, P.I.; Pietila, T.E.; Veckman, V.; Kotenko, S.V.; Julkunen, I. IFN regulatory factor family members differentially regulate the expression of type III IFN (IFN-lambda) genes. J. Immunol. 2007, 179, 3434-3442. [CrossRef] [PubMed]

23. Licastro, F.; Raschi, E.; Carbone, I.; Porcellini, E. Variants in Antiviral Genes are Risk Factors for Cognitive Decline and Dementia. J. Alzheimers Dis. 2015, 46, 655-663. [CrossRef] [PubMed]

24. Ransohoff, R.M. How neuroinflammation contributes to neurodegeneration. Science 2016, 353, 777-783. [CrossRef]

25. Fulop, T.; Larbi, A.; Pawelec, G. Human T cell aging and the impact of persistent viral infections. Front. Immunol. 2013, 4. [CrossRef]

26. Hollingworth, P.; Harold, D.; Sims, R.; Gerrish, A.; Lambert, J.C.; Carrasquillo, M.M.; Abraham, R.; Hamshere, M.L.; Pahwa, J.S.; Moskvina, V.; et al. Common variants at ABCA7, MS4A6A/MS4A4E, EPHA1, CD33 and CD2AP are associated with Alzheimer's disease. Nat. Genet. 2011, 43, 429-435. [CrossRef]

27. Lambert, J.C.; Heath, S.; Even, G.; Campion, D.; Sleegers, K.; Hiltunen, M.; Combarros, O.; Zelenika, D.; Bullido, M.J.; Tavernier, B.; et al. Genome-wide association study identifies variants at CLU and CR1 associated with Alzheimer's disease. Nat. Genet. 2009, 41, 1094-1099. [CrossRef] 
28. Licastro, F.; Porcellini, E. Persistent infections, immune-senescence and Alzheimer's disease. Oncoscience 2016, 3, 135-142. [CrossRef]

29. Costa Sa, A.C.; Madsen, H.; Brown, J.R. Shared Molecular Signatures Across Neurodegenerative Diseases and Herpes Virus Infections Highlights Potential Mechanisms for Maladaptive Innate Immune Responses. Sci. Rep. 2019, 9, 8795. [CrossRef]

30. Eimer, W.A.; Vijaya Kumar, D.K.; Navalpur Shanmugam, N.K.; Rodriguez, A.S.; Mitchell, T.; Washicosky, K.J.; Gyorgy, B.; Breakefield, X.O.; Tanzi, R.E.; Moir, R.D. Alzheimer's Disease-Associated beta-Amyloid Is Rapidly Seeded by Herpesviridae to Protect against Brain Infection. Neuron 2018, 100, 1527-1532. [CrossRef]

31. Harris, S.A.; Harris, E.A. Herpes Simplex Virus Type 1 and Other Pathogens are Key Causative Factors in Sporadic Alzheimer's Disease. J. Alzheimers Dis. 2015, 48, 319-353. [CrossRef]

32. Itzhaki, R.F.; Lathe, R.; Balin, B.J.; Ball, M.J.; Bearer, E.L.; Braak, H.; Bullido, M.J.; Carter, C.; Clerici, M.; Cosby, S.L.; et al. Microbes and Alzheimer's Disease. J. Alzheimers Dis. 2016, 51, 979-984. [CrossRef] [PubMed]

33. Kumar, D.K.; Choi, S.H.; Washicosky, K.J.; Eimer, W.A.; Tucker, S.; Ghofrani, J.; Lefkowitz, A.; McColl, G.; Goldstein, L.E.; Tanzi, R.E.; et al. Amyloid-beta peptide protects against microbial infection in mouse and worm models of Alzheimer's disease. Sci. Transl. Med. 2016, 8, 340ra372. [CrossRef] [PubMed]

34. Moir, R.D.; Lathe, R.; Tanzi, R.E. The antimicrobial protection hypothesis of Alzheimer's disease. Alzheimers Dement. 2018, 14, 1602-1614. [CrossRef] [PubMed]

35. Yang, Y.; Geldmacher, D.S.; Herrup, K. DNA replication precedes neuronal cell death in Alzheimer's disease. J. Neurosci. 2001, 21, 2661-2668. [CrossRef]

36. Grainger, D.J.; Reckless, J.; McKilligin, E. Apolipoprotein E modulates clearance of apoptotic bodies in vitro and in vivo, resulting in a systemic proinflammatory state in apolipoprotein E-deficient mice. J. Immunol. 2004, 173, 6366-6375. [CrossRef]

37. Laskowitz, D.T.; Lee, D.M.; Schmechel, D.; Staats, H.F. Altered immune responses in apolipoprotein E-deficient mice. J. Lipid Res. 2000, 41, 613-620.

38. Akwa, Y.; Hassett, D.E.; Eloranta, M.L.; Sandberg, K.; Masliah, E.; Powell, H.; Whitton, J.L.; Bloom, F.E.; Campbell, I.L. Transgenic expression of IFN-alpha in the central nervous system of mice protects against lethal neurotropic viral infection but induces inflammation and neurodegeneration. J. Immunol. 1998, 161, 5016-5026.

39. Esen, N.; Rainey-Barger, E.K.; Huber, A.K.; Blakely, P.K.; Irani, D.N. Type-I interferons suppress microglial production of the lymphoid chemokine, CXCL13. Glia 2014, 62, 1452-1462. [CrossRef]

40. Kovarik, P.; Castiglia, V.; Ivin, M.; Ebner, F. Type I Interferons in Bacterial Infections: A Balancing Act. Front. Immunol. 2016, 7, 652. [CrossRef]

41. Lambert, J.C.; Grenier-Boley, B.; Chouraki, V.; Heath, S.; Zelenika, D.; Fievet, N.; Hannequin, D.; Pasquier, F.; Hanon, O.; Brice, A.; et al. Implication of the immune system in Alzheimer's disease: Evidence from genome-wide pathway analysis. J. Alzheimers Dis. 2010, 20, 1107-1118. [CrossRef] [PubMed]

42. Guerriero, F.; Sgarlata, C.; Francis, M.; Maurizi, N.; Faragli, A.; Perna, S.; Rondanelli, M.; Rollone, M.; Ricevuti, G. Neuroinflammation, immune system and Alzheimer disease: Searching for the missing link. Aging Clin. Exp. Res. 2016. [CrossRef] [PubMed]

43. Miklossy, J. Handbook of Infection and Alzheimer's Disease. In Advances in Alzheimer's Disease Ser 5; Fairfax: Amsterdam, The Netherlands, 2017.

44. Braak, H.; Braak, E. Neuropathological stageing of Alzheimer-related changes. Acta Neuropathol. 1991, 82, 239-259. [CrossRef] [PubMed]

45. Braak, H.; Braak, E. Staging of Alzheimer's disease-related neurofibrillary changes. Neurobiol. Aging 1995, 16, 271-278. [CrossRef]

46. Penna, I.; Vella, S.; Gigoni, A.; Russo, C.; Cancedda, R.; Pagano, A. Selection of candidate housekeeping genes for normalization in human postmortem brain samples. Int. J. Mol. Sci. 2011, 12, 5461-5470. [CrossRef]

47. Livak, K.J.; Schmittgen, T.D. Analysis of relative gene expression data using real-time quantitative PCR and the 2(-Delta Delta C(T)) Method. Methods 2001, 25, 402-408. [CrossRef]

(C) 2020 by the authors. Licensee MDPI, Basel, Switzerland. This article is an open access article distributed under the terms and conditions of the Creative Commons Attribution (CC BY) license (http://creativecommons.org/licenses/by/4.0/). 